\title{
Chlorine Disinfection of Tomato Surface Wounds Contaminated with Salmonella spp.
}

\author{
K. Felkey ${ }^{1}$, D.L. Archer ${ }^{2}$, J.A. Bartz ${ }^{3}$, R.M. Goodrich², and \\ K.R. Schneider ${ }^{2,4}$
}

AdDitional INDEX WORDs. produce, vegetable, bacteria, contamination

SUMMARY. This study examined the efficacy of chlorine treatments of flume water for eliminating Salmonella spp. from inoculated wounds and intact surfaces of tomatoes (Lycopersicon esculentum). Water in a scale-model flume was chlorinated to $150 \mathrm{mg} \cdot \mathrm{L}^{-1}$ of free chlorine at $\mathrm{pH} 6.5$ and maintained at a temperature of 25 or $35^{\circ} \mathrm{C}$, depending on the test. Viable Salmonella were recovered from all of the inoculation sites (intact fruit surface, punctures, shaves, and stem scars) even after treatment with chlorinated water for up to 120 seconds at either 25 or 35 ${ }^{\circ} \mathrm{C}$. Generally, the highest Salmonella recovery came from puncture wounds and the lowest from the intact surfaces. After 120 seconds at $25^{\circ} \mathrm{C}, 4.9$ to $5.8 \log _{10}$ units were recovered from the wounds. Populations recovered after the 30 -second treatment at $35^{\circ} \mathrm{C}$ ranged from $4.1 \log _{10} \mathrm{cfu} / \mathrm{mL}$ for intact surfaces to 6.0 $\log _{10} \mathrm{cfu} / \mathrm{mL}$ in the puncture wounds. At 60 - and 120 -second treatment times, all wounds had higher mean populations than tomatoes with intact surfaces. Although greater Salmonella survival was associated with shorter exposure to the chlorine, water chlorination cannot completely eliminate contamination of tomato fruit by Salmonella, even on intact surfaces. Stem scars, in this study, were not readily disinfected with sodium hypochlorite.

A consumer eating raw tomatoes ingests various microorganisms that reside on or in the fruit. Like other fresh fruit and vegetables, tomatoes are not sterile (Samish and Etinger-Tulczynska, 1963). Good agricultural practices (GAPs) dictate that growers take steps to prevent tomato crops from contacting potential sources of harmful microorganisms. For example, most tomato fields begin as transplants set into bedded soil that is covered with plastic mulch (Rushing et al., 1996). As the plants grow, they are tied to stakes. Developing fruit rarely if ever contact the soil. However, some soil can get on fruit from dust or rain splash. Irrigation is typically drip or overhead (Hochmuth, 1998). Although drip irrigation restricts fruit contact with water, Sadovski et al. (1978) observed that tomatoes

Acknowledgments. This work was funded in part by the USDA-CSREES IFAFS Grant number 00-52102 9637 and a grant from the Florida Tomato Committee. This is Florida Agricultural Experiment Station Journal Series number R-10775.

${ }^{1}$ Division of Consolidated Laboratory Services, Commonwealth of Virginia, 600 N. 5th St., Rm. 272, Richmond, VA 23219

${ }^{2}$ Food Science and Human Nutrition Department, University of Florida, 359 FHSN Bldg., Newell Dr., Gainesville, FL 32611-0370.

${ }^{3}$ Plant Pathology Department, University of Florida, PO Box 110680, Gainesville, FL 32611-0680.

${ }^{4}$ To whom reprint requests should be addressed; phone: (352) 392-1991, ext. 313; fax: (352)392-9467; e-mail: krschneider@ifas.ufl.edu drip irrigated with wastewater could become contaminated. By contrast, with overhead irrigation fruit become wetted by water with each application. Thus, use of any source of non-potable water can lead to fruit contamination. Guo et al. (2001) detected Salmonella in ripe tomatoes that had been inoculated when the plants were blossoming. Clearly, a single point-source of contamination can lead to the survival of human pathogens on plants for several weeks.

During harvest for the fresh market, tomatoes are hand-picked and placed in large plastic or wooden buckets that hold 40 to $50 \mathrm{lb}$ of fruit. These buckets are then dumped into pallet bins with a capacity of about $1200 \mathrm{lb}$ of fruit (Sargent, 1998). Alternatively, field buckets are emptied into large tractor trailers that can contain several thousand pounds of fruit. The entire field harvest operation is labor intensive. Workers are paid on a piece-rate basis that rewards speed and efficiency. Rapid harvest motions and bucket unloading promotes fruit injuries. Any damage to the fruit surface facilitates internalization of various forms of microorganisms. Additionally, spoilage organisms such as Erwinia carotovora, Geotrichum candidum, Rhizopus stolonifera, and Botrytis cinerea (Sargent, 1998) may grow on the surface of damaged tissues or in unprotected tissues within fruit (Bartz and Wei, 2003). Wells and Butterfield (1997) reported a high incidence of Salmonella in association with decayed vegetable samples from supermarket produce displays. Bacterial soft rot appeared to promote the survival of Salmonella in co-inoculation tests.

Upon reaching the packinghouse, tomatoes are dumped into flume tanks containing 100 to $150 \mathrm{mg} \cdot \mathrm{L}^{-1}$ of free chlorine, typically at a $\mathrm{pH}$ of 6.5 to 7 , and at a temperature about $5{ }^{\circ} \mathrm{C}$ above fruit pulp (Bartz et al., 2001). Chlorination of the water in the tanks is intended to prevent the fruit from becoming cross-contaminated by an accumulation of undesirable microorganisms. The flume water is maintained at about $5{ }^{\circ} \mathrm{C}$ above the temperature of the incoming fruit to prevent subsequent flume water and microbial infiltration into the fruit through the stem scar. Upon leaving the flume, tomatoes are conveyed past workers who remove fruit with defects such as excessive color, misshapen physical appearance, decay lesions, or injuries such as cuts or bruises. Small wounds, however, may escape detection. Microorganisms, including Salmonella spp., have been reported to survive better in wounded tissues, whereas populations located on the smooth surfaces fail to survive as well (Beuchat and Ryu, 1997). In three studies on tomatoes and chlorine efficacy, Salmonella spp. were inoculated on whole tomatoes as well as stem scars and wounds (Wei et al., 1995; Weissinger et al., 2000; Zhuang et al., 1995). Wei et al. (1995) inoculated Salmonella Montevideo on whole tomatoes, stem scars, growth cracks, and punctures. The tomatoes were treated with $100 \mathrm{mg} \cdot \mathrm{L}^{-1}$ chlorine

\begin{tabular}{llll}
\hline $\begin{array}{l}\text { Units } \\
\begin{array}{l}\text { To convert U.S. to SI, } \\
\text { multiply by }\end{array}\end{array}$ & U.S. unit & SI unit & $\begin{array}{l}\text { To convert SI to U.S., } \\
\text { multiply by }\end{array}$ \\
\hline 29,574 & $\mathrm{fl} \mathrm{oz}$ & $\mu \mathrm{L}$ & $3.3814 \times 10^{-5}$ \\
29.5735 & $\mathrm{fl} \mathrm{oz}$ & $\mathrm{mL}$ & 0.0338 \\
25.4000 & inch $(\mathrm{es})$ & $\mathrm{mm}$ & 0.0394 \\
0.4536 & $\mathrm{lb}$ & $\mathrm{kg}$ & 2.2046 \\
1 & $\mathrm{ppm}$ & $\mathrm{mg} \cdot \mathrm{L}^{-1}$ & 1 \\
$\left({ }^{\circ} \mathrm{F}-32\right) \div 1.8$ & ${ }^{\circ} \mathrm{F}$ & ${ }^{\circ} \mathrm{C}$ & $\left(1.8 \times{ }^{\circ} \mathrm{C}\right)+32$
\end{tabular}


for up to $2 \mathrm{~min}$ and reductions were only 1.0 to $2.0 \log _{10}$ units. Weissinger et al. (2000) treated tomatoes inoculated with Salmonella Baildon by dipping the whole tomato in 120 and $200 \mathrm{mg} \cdot \mathrm{L}^{-1}$ of chlorine for $40 \mathrm{~s}$. Tomatoes were still positive for Salmonella after the $200 \mathrm{mg} \cdot \mathrm{L}^{-1}$ treatment and populations with both treatments were reduced by less than a $1.0 \log _{10} \mathrm{cfu} / \mathrm{mL}$. Zhuang et al. (1995) treated tomatoes with 0 , $50,110,200$, and $320 \mathrm{mg} \cdot \mathrm{L}^{-1}$ of chlorine after inoculating with Salmonella Montevideo. Whole tomatoes and core tissues were sampled for Salmonella survival. Even at $320 \mathrm{mg} \cdot \mathrm{L}^{-1}$, populations of Salmonellawere not eliminated (Zhuang et al., 1995).

This study examined the efficacy of chlorine treatment of flume water for eliminating Salmonella spp. from inoculated wounds and intact surfaces, using treatment conditions (free chlorine level, $\mathrm{pH}$, and flume water temperatures) currently utilized in Florida fresh tomato packinghouses.

\section{Materials and methods}

Cultures. Bacterial strains associated with fruit- and vegetable-related foodborne illness outbreaks were obtained from University of California, Davis (L. Harris). These Salmonella cultures were adapted to be rifampin resistant (rif+) to a level of $200 \mathrm{mg} \cdot \mathrm{L}^{-1}$. The serovars used in this study were Salmonella Agona, Salmonella Gaminara, Salmonella Michigan, Salmonella Montevideo, and Salmonella Poona. All media used in growth studies and experiments were supplemented with $80 \mathrm{mg} \cdot \mathrm{L}^{-1}$ of rifampin (Fisher, Fair Lawn, N.J.) (rift) so that Salmonella cells isolated from inoculated tomatoes were relatively free of competition from other bacterial contaminants (Lukasik et al., 2001). The cultures were maintained on tryptic soy agar [TSA (BD Diagnostics, Franklin Lakes, N.J.)] slants. The inoculum was prepared from a successive 3 -d transfer in tryptic soy broth [TSB (BD Diagnostics)] supplemented with 80 $\mathrm{mg} \cdot \mathrm{L}^{-1}$ of rifampin. The cultures were centrifuged at $3220 \mathscr{g}_{\mathrm{n}}$ for $20 \mathrm{~min}$ and washed twice with phosphate buffer saline [PBS (Sigma-Aldrich, St. Louis, Mo.)]. All five strains were combined as a cocktail and diluted in PBS to obtain an approximate inoculum level of $1.0 \times$ $10^{9} \mathrm{cfu} / \mathrm{mL}$ of inoculum cocktail.

WOUnds (shaves, PUNCTURes, AND STEM SCARS). All tomatoes used in this study were round, unripe, green 'Florida 47' tomatoes. Tomatoes were obtained from a commercial packinghouse prior to any treatment. Salmonella recovery was tested on four surface types: intact, punctures, shaves, and stem scars. For puncture tests, three wounds per tomato were made using a sharp, thin strand of sterile metal (approximately $\mathrm{l} \mathrm{mm}$ thick) to a depth of $1 \mathrm{~mm}$. For shaved wounds, a section of the fruit surface was removed to a depth of about 1 $\mathrm{mm}$ with a sterile scalpel over an area of approximately $15 \mathrm{~mm}$ in diameter. Stem scars represent a common natural wound associated with the removal of stems from the fruit. There were three replicate samples prepared for each wound type. Three replicates of whole, intact tomatoes were utilized as non-wounded surface controls, and a water control (flume water at the same temperature and $\mathrm{pH}$ as the chlorinated flume treatment) was performed in order to evaluate the degree of Salmonella reduction from the intact fruit surface due to mechanical action only. The water control represents the maximum decontamination effect that could be achieved by the mechanical action of the flume water.

INOCULATION AND $S_{A L M O N E L L A}$ RECOVERY. For puncture wounds, a 10- $\mu \mathrm{L}$ aliquot of the Salmonella cocktail was placed in each of the three punctures on each tomato. The shave wounds, stem scars, and intact surfaces all received $100-\mu \mathrm{L}$ aliquots of the inoculum. The inoculum was appropriately diluted to deliver the same titer of Salmonella per tomato for each surface type. The inoculated areas were identified with indelible marker and the inoculum was then allowed to air-dry at room temperature for approximately $\mathrm{l} \mathrm{h}$. As soon as the drying was completed, three replicate samples from each of the four surface types were removed with a sterile knife and placed into a sterile Stomacher bag (Seward, Norfolk, U.K.) containing $100 \mathrm{~mL}$ Butterfield's phosphate buffer (BPB) supplemented with $0.1 \%$ sodium thiosulfate to determine initial populations $(t=0 \mathrm{~s})$. Counts were recorded as surviving Salmonella $\mathrm{cfu} / \mathrm{mL}$ in recovery buffer.

Flume treatments. Water in a scale-model flume was chlorinated to $150 \mathrm{mg} \cdot \mathrm{L}^{-1}$ of free chlorine at $\mathrm{pH}$ 6.5 and maintained at a temperature of 25 or $35{ }^{\circ} \mathrm{C}$, depending on the test. Residual free chlorine levels were measured using a Hach DR-890 (Hach Co., Loveland, Colo.). Temperature, chlorine concentration, and $\mathrm{pH}$ measurements were conducted at the beginning and end of each flume treatment to ensure treatment conditions were maintained as stated throughout each run. Inoculated fruit, tempered to room temperature and oriented such that the inoculated areas were fully submerged in the chlorinated water, were floated in the flume for the stated treatment duration. The experiments were also conducted with a water control (no free chlorine) at 25 and $35^{\circ} \mathrm{C}$ to represent the pathogen reduction due to water rinsing only. For all treatments, three replicate tomato samples were removed after 30,60 , and 120 s. The inoculated sites were removed and Salmonella populations were determined using the same procedures described for the $t=0$ samples.

Statistics. The means of populations recovered from different inoculation sites (wound types) and chlorination treatment in two separate experiments were compared using analysis of variance (ANOVA)/multivariate analysis of variance (MANOVA) and Duncan's multiple range statistics (Statsoft Statistica, Tulsa, Okla.).

\section{Results}

Determination OF EFFicACY AT $150 \mathrm{MG} \cdot \mathrm{L}^{-1}$ OF FREE CHLORINE, $\mathrm{PH}$ 6.5, AND 25 AND $35^{\circ} \mathrm{C}$. $\log _{10}$ values of 6.5 to 6.8 and 5.8 to $6.5 \mathrm{cfu} / \mathrm{mL}$ were recovered from the different inoculation sites prior to the chlorine treatment $(\mathrm{t}=0 \mathrm{~s})$ at $25^{\circ} \mathrm{C}$ (Table 1) and $35{ }^{\circ} \mathrm{C}$ (Table 2$)$, respectively. The $t=0 \mathrm{~s}$ values represented the initial inoculum level of untreated fruit and are the values from which $\log$ reductions were determined. Viable Salmonella were recovered from all of the inoculation sites, including the intact fruit surface, even after treatment with chlorinated water for up to 120 $\mathrm{s}$ at either 25 or $35^{\circ} \mathrm{C}$. Water control numbers represent the $\log _{10}$ survivors after exposure to non-chlorinated water for $\mathrm{t}=0$ to $120 \mathrm{~s}$.

After a 30-s exposure in the chlorine bath, $\log _{10} 3.5$ to $5.9 \mathrm{cfu} / \mathrm{mL}$ were recovered from the different inoculation sites (Table 1). Generally, the highest Salmonella recovery came from puncture wounds and the lowest from the intact surfaces. After $120 \mathrm{~s}$ at $25{ }^{\circ} \mathrm{C}$, nearly all Salmonella had 
Table 1. Salmonella $\log _{10}$ survivors recovered from tomato inoculated sites after simulated flume treatment of $0,30,60$, and $120 \mathrm{~s}$ at $25^{\circ} \mathrm{C}\left(77.0{ }^{\circ} \mathrm{F}\right)$ [free chlorine $150 \mathrm{mg} \cdot \mathrm{L}^{-1}(\mathrm{ppm})$ and $\mathrm{pH} 6.5$ ] and water control at $25{ }^{\circ} \mathrm{C}$ (free chlorine $0 \mathrm{mg} \cdot \mathrm{L}^{-1}, \mathrm{pH} 6.5$, intact fruit).

\begin{tabular}{llcccc}
\hline & \multicolumn{4}{c}{ Salmonella survivors $(\log \mathrm{cfu} / \mathrm{mL})$ recovered from inoculation site } \\
\cline { 2 - 6 } Treatment & \multicolumn{1}{c}{ Stem scar } & Scrape & Puncture & Intact & Water control $^{\mathrm{y}}$ \\
\hline $0 \mathrm{~s}$ & $6.77 \pm 0.17 \mathrm{a}$ & $6.52 \pm 0.16 \mathrm{a}$ & $6.56 \pm 0.34 \mathrm{a}$ & $6.52 \pm 0.48 \mathrm{a}$ & $5.99 \pm 0.29 \mathrm{~d}$ \\
$30 \mathrm{~s}$ & $5.80 \pm 0.38 \mathrm{a}, \mathrm{b}$ & $4.82 \pm 0.79 \mathrm{~b}$ & $5.92 \pm 0.20 \mathrm{a}$ & $3.49 \pm 0.64 \mathrm{c}$ & $4.94 \pm 0.39 \mathrm{e}$ \\
$60 \mathrm{~s}$ & $5.16 \pm 0.66 \mathrm{a}$ & $5.34 \pm 0.64 \mathrm{a}$ & $5.85 \pm 0.50 \mathrm{a}$ & $3.29 \pm 0.71 \mathrm{~b}$ & $5.06 \pm 0.20 \mathrm{e}$ \\
$120 \mathrm{~s}$ & $4.91 \pm 0.17 \mathrm{a}$ & $5.10 \pm 1.04 \mathrm{a}$ & $5.83 \pm 0.13 \mathrm{a}$ & $0.16 \pm 0.28 \mathrm{~b}$ & $4.57 \pm 0.27 \mathrm{e}$ \\
\hline
\end{tabular}

${ }^{2}$ Mean \pm SD for triplicate determinations. For chlorination results, means with the same letter in the same row are not significantly different $(P>$ $0.05)$.

'For water control only, means with the same letter in the same column are not significantly different $(P>0.05)$.

Table 2. Salmonella $\log _{10}$ survivors recovered from tomato inoculated sites after simulated flume treatment of $0,30,60$ and $120 \mathrm{~s}$ at $35^{\circ} \mathrm{C}\left(95.0{ }^{\circ} \mathrm{F}\right)$ [free chlorine $150 \mathrm{mg} \cdot \mathrm{L}^{-1}(\mathrm{ppm})$ and $\mathrm{pH} 6.5$ ] and water control at $35^{\circ} \mathrm{C}$ (free chlorine $0 \mathrm{mg} \cdot \mathrm{L}^{-1}, \mathrm{pH} 6.5$, intact fruit).

\begin{tabular}{lccccc}
\hline & \multicolumn{4}{c}{ Salmonella survivors } & $(\log \mathrm{cfu} / \mathrm{mL})$ recovered from inoculation site $^{\mathrm{z}}$ \\
\cline { 2 - 6 } Treatment & Stem scar & Scrape & Puncture & Intact & Water control $^{\mathrm{y}}$ \\
\hline $0 \mathrm{~s}$ & $6.48 \pm 0.66 \mathrm{a}$ & $5.77 \pm 0.28 \mathrm{a}$ & $6.49 \pm 0.09 \mathrm{a}$ & $6.34 \pm 0.28 \mathrm{a}$ & $5.60 \pm 0.54 \mathrm{~d}$ \\
$30 \mathrm{~s}$ & $5.59 \pm 0.17 \mathrm{a}$ & $5.65 \pm 0.31 \mathrm{a}$ & $6.00 \pm 0.11 \mathrm{a}$ & $4.06 \pm 2.03 \mathrm{a}$ & $4.84 \pm 0.13 \mathrm{e}$ \\
$60 \mathrm{~s}$ & $5.76 \pm 0.30 \mathrm{a}$ & $5.43 \pm 0.19 \mathrm{a}$ & $5.67 \pm 0.14 \mathrm{a}$ & $2.81 \pm 2.58 \mathrm{~b}$ & $4.74 \pm 0.13 \mathrm{e}$ \\
$120 \mathrm{~s}$ & $5.48 \pm 0.18 \mathrm{a}$ & $5.21 \pm 0.06 \mathrm{a}$ & $5.78 \pm 0.15 \mathrm{a}$ & $1.49 \pm 2.58 \mathrm{~b}$ & $4.24 \pm 0.65 \mathrm{e}$ \\
\hline
\end{tabular}

${ }^{2}$ Mean \pm SD for triplicate determinations. For chlorination results, means with the same letter in the same row are not significantly different $(P>$ 0.05 ).

${ }^{y}$ For water control only, means with the same letter in the same column are not significantly different $(P>0.05)$.

been eliminated from intact surfaces, whereas 4.9 to $5.8 \log _{10}$ units were recovered from the various wounds. The largest populations were recovered from the puncture wound sites and the smallest from the stem scar area; however, these values were not different from each other. Populations recovered from the scrape wounds were similar to those extracted from the stem scar sites. Exposure of intact fruit to non-chlorinated water at the various treatment times did not result in significant differences in recovered Salmonella populations.

Populations recovered after the 30 -s chlorination treatment at $35{ }^{\circ} \mathrm{C}$ ranged from $\log _{10} 4$.1 for intact surfaces to $6.0 \mathrm{cfu} / \mathrm{mL}$ in the puncture wounds (Table 2). At the 60- and 120-s treatment times, all wounds had higher mean populations than tomatoes with intact surfaces. After the 120-s treatment, mean populations recovered from wounds ranged from $\log _{10} 5.2$ to $5.8 \mathrm{cfu} / \mathrm{mL}$, whereas the intact surface had a mean recovered value of $\log _{10}$ $1.5 \mathrm{cfu} / \mathrm{mL}$. Flume treatment with the non-chlorinated water resulted in a significant decrease in initial populations for all exposure times, although there were no significant differences among the exposure times themselves.

The $25{ }^{\circ} \mathrm{C} \log _{10}$ reductions over $120 \mathrm{~s}$ ranged from 0.7 for punctures to 6.4 for intact tomatoes (Fig. 1 ). The largest reduction of Salmonella was observed with intact tomatoes. Similar reductions in Salmonella counts were observed in the $35^{\circ} \mathrm{C}$ trials.

\section{Discussion}

Areas on or in tomatoes that enable bacteria to become embedded in the fruit tissues could provide protection for Salmonella in an aqueous chlorinated environment. Wells and Butterfield (1999) found that the incidence of Salmonella on produce was higher on items that had decay caused by bacteria or fungi or had physical injury than on those that were injury and decay free. The wounds offer not only protection against desiccation and other stresses, but also an environment conducive to multiplication (Wells and Butterfield, 1999). Zhuang et al. (1995) demonstrated chlorine dip treatments were less effective in reducing Salmonella populations in core tissues than on those on tomato surfaces. Wei et al. (1995) reported the failure of water chlorination to remove Salmonella from stem scars and growth cracks.

Under certain conditions, the

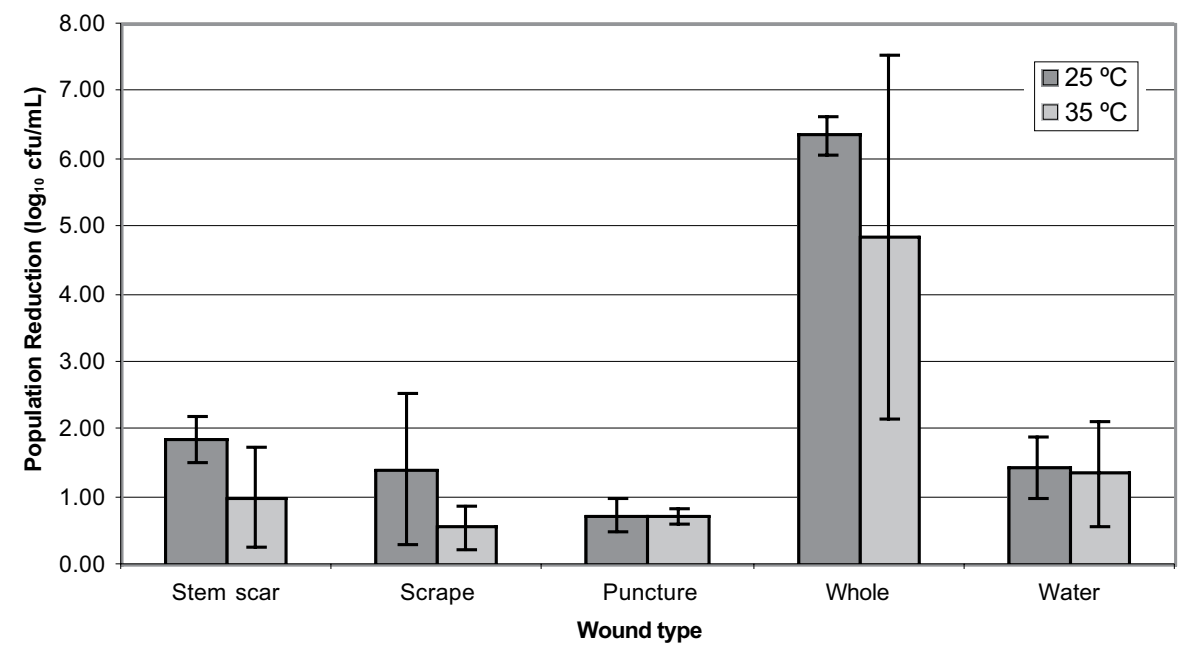

Fig. 1. $\log _{10}$ reductions of Salmonella populations after a 120 -s treatment of $150 \mathrm{mg} \cdot \mathrm{L}^{-1}(\mathrm{ppm})$ free chlorine at $\mathrm{pH} 6.5$. Trials were performed at 25 and 35 ${ }^{\circ} \mathrm{C}\left(77.0\right.$ and $\left.95.0^{\circ} \mathrm{F}\right)$. Each bar represents the mean of three replicate samples. 
stem scar and wounds on tomato can offer routes by which aqueous suspensions of bacteria can become internalized. Bartz and Showalter (1981) reported that if fruit were immersed in an environment, such as a flume tank, that was cooler than the fruit, bacterial suspensions could infiltrate the stem scars on tomatoes as the fruit cooled. Bartz et al. (2001) noted that water-soluble dyes rapidly penetrated into freshly wounded tissues of tomato fruit where sap from damaged cells flooded nearby intercellular spaces. Johnson (1945) reported that bacteria internalized in tobacco leaf tissues if the surface openings were water-congested and further, suggested that capillary forces in the intercellular spaces were involved. When bacterial suspensions are in intercellular spaces, liquid disinfectants appear to displace the suspensions further into the tissues (Bartz et al., 2001).

In the $25^{\circ} \mathrm{C}$ study, with tomatoes that were inoculated with an aqueous cell suspension of Salmonella that was allowed to dry on the unbroken surface, populations were reduced up to $6.4 \mathrm{log}$ units by a 2 -min immersion treatment with chlorinated water at $150 \mathrm{mg} \cdot \mathrm{L}^{-1}$ ( $\mathrm{pH} 6.5$ at $25^{\circ} \mathrm{C}$ ). By contrast, populations placed in wounds were reduced by only 0.6 to $1.9 \mathrm{log}$ units, depending on the test and the type of wound. Greater survival with each type of inoculation site, including stem scar, unbroken surface, puncture, or scrape, was associated with shorter exposure to the chlorine.

In the second study, tomatoes were placed in flume water at a temperature of $35^{\circ} \mathrm{C}$ to establish a $+10^{\circ} \mathrm{C}$ temperature differential between the flume water and the fruit. This simulates the optimal commercial practice of maintaining the flume water at a warmer temperature than the incoming fruit in order to prevent possible bacterial infiltration. Theoretically, use of warmer chlorine solutions should lead to increased activity of the hypochlorous acid (White, 1999). One would expect improved wound sanitization at $35^{\circ} \mathrm{C}$, as compared to results at 25 ${ }^{\circ} \mathrm{C}$, due to this increased sanitization activity. However, this study did not demonstrate any increase in efficacy at $35^{\circ} \mathrm{C}$ (Fig. 1). This could be due to the reduced tendency of the sanitizing solution to infiltrate the wounded areas due to the temperature differential. After a 60-s treatment, significantly fewer Salmonella were recovered from the unbroken surfaces as compared with the wounds (Tables 1-2). In the $35{ }^{\circ} \mathrm{C}$ study, the 120 -s-treated, intact tomatoes demonstrated a $4.9 \log _{10}$ reduction, whereas the $\log _{10}$ reduction with the stem scar, puncture, and scrape wounds averaged 1.0, 0.7, and 0.6 , respectively.

Clearly, water chlorination cannot be relied upon to eliminate contamination of tomato fruit by Salmonella, particularly if these bacteria have gained entry into the fruit through wounds prior to sanitation. Any tomatoes that have wounds, such as punctures, cuts, or scrapes, must be culled at the packinghouse to minimize the chance of Salmonella contamination. Stem scars are a naturally occurring consequence of harvesting tomatoes and therefore cannot be avoided. However, this study suggests stem scars, as with the wounds examined in this study, cannot be readily disinfected through the use of the industry standard sanitizer, sodium hypochlorite. Thus, it is imperative for tomato growers to minimize or prevent contamination through the use of good agricultural practices prior to and during harvesting. Additionally, the equipment used during the harvest must be kept sanitized and field crews must be properly trained and use good hygienic practices. Proper and continuous water chlorination is required at the packinghouse, as recommended by U.S. Food and Drug Administration (1998). This study shows Salmonella populations were reduced when fruit surfaces were intact. Finally, the packing equipment, fruit boxes, and transportation equipment must be kept clean, new, and/or sanitized to prevent cross-contamination.

\section{Literature cited}

Bartz, J.A., C.G. Eayre, M.J. Mahovic, D.E. Concelmo, J.K. Brecht, and S.A. Sargent. 2001. Chlorine concentration and the inoculation of tomato fruit in packinghouse dump tanks. Plant Dis. 85:885-889.

Bartz, J.A. and R.K. Showalter. 1981. Infiltration of tomatoes by aqueous bacterial suspensions. Phytopathology 71:515-518.

Bartz, J.A. and C.I. Wei. 2003. The influence of bacteria, p. 519-541. In: J.A. Bartz and J.K. Brecht (eds.). Postharvest physiology and pathology of vegetables. Marcel Dekker, New York.

Beuchat, L.R. and J.H. Ryu. 1997. Produce handling and processing practices. Emerging Infectious Dis. 3:459-465.

Guo, X., J. Chen, R.E. Brackett, and L.R.
Beuchat. 2001. Survival of salmonellae on and in tomato plants from the time of inoculation at flowering and early stages of fruit development through fruit ripening. Appl. Environ. Microbiol. 67:4760-4764.

Hochmuth, G.J. 1998. Tomato production guide for Florida: Fertilization. Coop. Ext. Serv., Inst. Food Agr. Sci., Univ. of Florida EDIS Publ. SP-214.

Johnson, J. 1945. Infection experiments with detached water-congested leaves. Phytopathology 1017-1028.

Lukasik, J., M.L. Bradley, T.M. Scott, W. Hsu, S.R. Farrah, and M.L. Tamplin. 2001. Elution, detection and quantification of polio 1 , bacteriophages, Salmonella Montevideo and Escherichia coli O157:H7 from seeded strawberries and tomatoes. J. Food Protection 64:292-297.

Rushing, J.W., F.J. Angulo, and L.R. Beuchat. 1996. Implantation of a HACCP program in a commercial fresh-market tomato packinghouse: A model for the industry. Dairy Food Environ. Sanitation 16:549-553.

Sadovski, A.Y., B. Fattal, D. Goldberg, E. Katzenelson, and H.I. Shuval. 1978. High levels of microbial contamination of vegetables irrigated with wastewater by the drip method. Appl. Environ. Microbiol. 36:824-830.

Samish, Z. and R. Etinger-Tulczynska. 1963. Distribution of bacteria within the tissue of healthy tomatoes. Appl. Microbiol. 11:10-17.

Sargent, S.A. 1998. Tomato production guide for Florida: Harvest and handling. Coop. Ext. Serv., Inst. Food Agr. Sci., Univ. of Florida EDIS Publ. SP-214.

U.S. Food and Drug Administration. 1998. Guide to minimize microbial food safety hazards for fresh fruits and vegetables. FDA, Ctr. for Food Safety and Appl. Nutr. 15 Apr. 2005. <http://www.cfsan.fda.gov/ acrobat/prodguid.pdf>.

Wei, C.I., T.S. Huang, J.M. Kim, W.F. Lin, M.L. Tamplin, and J.A. Bartz. 1995. Growth and survival of Salmonella montevideo on tomatoes and disinfection with chlorinated water. J. Food Protection 58:829-836.

Weissinger, W.R., W. Chantarapanont, and L.R. Beuchat. 2000. Survival and growth of Salmonella baildon in shredded lettuce and diced tomatoes, and effectiveness of chlorinated water as a sanitizer. Intl. J. Food Microbiol. 62 (1-2):123-131.

Wells, J.M. and J.E. Butterfield. 1997. Salmonella contamination associated with bacterial soft rot of fresh fruits and vegetables in the marketplace. Plant Dis. 81:867-872.

Wells, J.M. and J.E. Butterfield. 1999. Incidence of Salmonella on fresh fruits and vegetables affected by fungal rots or physical injury. Plant Dis. 83:722-726.

White, C. 1999. Handbook of chlorination and alternative disinfectants. Wiley, New York.

Zhuang, R.Y., L.R. Beuchat, and F.J. Angulo.1995. Fate of Salmonella montevideo on and in raw tomatoes as affected by temperature and treatment with chlorine. Appl. Environ. Microbiol. 61:2127-2131. 